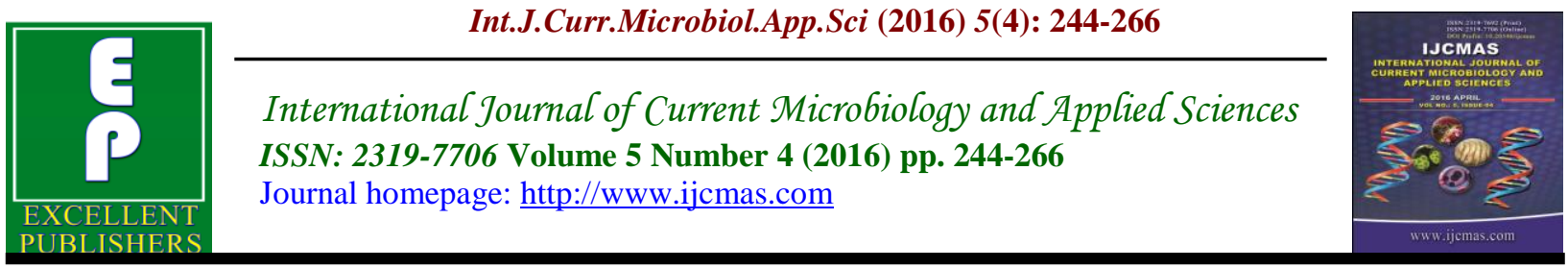

Review Article

http://dx.doi.org/10.20546/ijcmas.2016.504.030

\title{
Toxic Pollution in River Water and Bacterial Remediation: An Overview
}

\author{
Nupur Raghav and J.N Shrivastava*
}

\author{
Microbiology Laboratory, Department of Botany, Dayalbagh Educational \\ Institute, Dayalbagh, Agra-282005, India \\ *Corresponding author
}

\begin{abstract}
A B S T R A C T
Keywords

Accumulation,

Biological Oxygen

Demand,

Industrialization,

Urbanization,

Water Quality

Management.

Article Info

Accepted:

15 March 2016

Available Online:

10 April 2016

The quality of water is of fundamental concern for mankind because it is directly linked with human welfare. Approximately 30,000 people die every day in developing countries of the world because of unsanitary water supply, surveyed by World Health Organization in 1980. The addition of various kinds of pollutants and nutrients through sewage, agricultural runoff and industrial effluents into the water bodies result in a sequence of changes in the physicochemical characteristics of water. The pollution levels in the Yamuna river water have rise, biochemical oxygen demand (BOD) load has increased by 117 tonnes per day (TDP) in 1980 to 276 TDP in 2005. River provides valuable drinking water to humans, habitat to many aquatic plants and living organisms and irrigation water to farmlands. Excessive industrialization and consequent urbanization has led to several problems of water quality management of rivers. This paper makes an effort to highlight the status of Yamuna water quality, discusses the impact of heavy metals and pesticides on human health and the remediation of pollutants through bacterial isolates for better river water quality and quantity.
\end{abstract}

\section{Introduction}

The major cause of global concern which leads to onset of numerous fatal diseases is water pollution which is responsible for the death of over 14,000 people every day. Water pollution is defined as any destruction in its native characteristics by addition of anthropogenic contaminants, which disturb the normal use of water either it cannot serve to human for drinking purposes and/or to support the biotic communities. The problem of water pollution is more frightening in developing countries in comparison to industrialized nations. The major changes in the ecological status and water quality caused due to natural disasters like earthquakes, volcanoes, algal blooms and storm. Fresh water is limited resource, vital for agriculture, industry and even human existence, without fresh water of adequate quantity and quality, sustainable development will not be possible. The accumulation of various kinds of pollutants and nutrients through sewage, industrial effluents and agricultural runoff into the water bodies bring about a series of changes in the physicochemical and characteristics of water, which have been the subject matter of several investigations. Almost $50 \%$ of the 
water pollution of streams and rivers occur due to leaching and mixing of chemicals from the agriculture practices, according to a report published in 1990 from the Environment Protection Agency (EPA). According to UN surveyed reports, India is predictable to face critical levels of water stress by 2025 and there will be serious water shortages.

Environmental contamination and pollution have resulted extensively due to Industrialization and extraction of natural resources. The major problem that the whole world is facing today is contamination of soils, groundwater, sediments, surface water, and air with hazardous heavy metals and toxic chemicals. The remediation of these natural resources (soil, water and air) has led to the expansion of new technologies that put emphasis on the destruction of the pollutants rather than the conventional approach of disposal because of their potential to enter the food chain. In India, alarming levels of pesticides have been reported in air, water, soil as well as in foods and biological materials. Some of these pesticides have also been reported to be toxic, mutagenic, carcinogenic and tumorogenic. The most important pollutants among the toxicants in India are organochlorine and organophosphorus pesticides. For the past several decades, organochlorine pesticides have been widely used for both agricultural and public health purposes, but there is always a tendency to use them in excess. Microorganisms are important in maintaining soil fertility and are also important agents which detoxify pesticides in soil. Thus chemicals which seriously affect the soil microflora may harm soil fertility and crop production.

Rivers, though most important water resources of the world are being polluted by indiscriminate disposal of sewage, industrial wastes and a plethora of human activities. Pollution of rivers first affecting its physicochemical quality systematically destroys the biotic community disrupting the delicate food web. However pollution has several dimensions and the effective monitoring and the control of river pollution requires the expertise from various disciplines. There are fourteen major rivers in India and the reports of Saxena and Chauhan and those of CPCB indicate that majority of them are polluted. The river Yamuna, once a river of mythical status, today breeds malaria, cholera and jaundice diseases which claim the lives of thousands of living beings. Environmentalists bewail the degradation of the $1367 \mathrm{~km}$ of Yamunathe largest tributary of India holy river, the Ganges that originates from 6387 meters high glacier in the Himalayas.

\section{Literature Survey}

\section{Physico-Chemical Parameters}

The life on earth depends upon water among all three state in which water occur in the ecosphere as gas, solid and liquid only because the last one is an indispensable resource as far as human activity is concerned. Kumar et al., studied the effect of microbial mixture of various bacterial species such as Citrobacter, Klebsiella, Yersinia, Serratia, for the biodegradation of organic matter in sewage water. A significant variation in the physico-chemical parameters BOD $(84.9 \%)$ and COD $(79.9 \%)$ and DO (62.4\%) were reported by Mishra and Tripathi. Joshi and Sharma through their research work revealed that maximum reduction in Biological Oxygen Demand (79.45\%) and Chemical Oxygen Demand $(72.25 \%)$ was observed after bacterial inoculation period of 72 hours. Microbes used in Effective Microbes technology are 
non- harmful, non-pathogenic, nongenetically engineered or modified and nonchemically synthesized. Microbes originated from their own environment previously exposed to organic substances have greater degradation ability of related waste in biodegradation process Shrivastava et al.

A laboratory scale study has been carried out by Raghav et al. to reduce the load of BOD, COD, hardness, alkalinity, acidity, dissolved solids, suspended solids, total solids by the process of bioremediation using bacterial consortium. The bacterial consortium treated water sample showed a sharp reduction in BOD i.e. $89 \%$ and $84 \%$ in COD. The result of the study indicates that Effective bacterial consortium helps in the reduction of water impurities. The observation revealed that the inoculation of bacterial consortium in water may release the nutrients through biodegradation of the organic/inorganic matter of water sources, which promote the plant growth.

\section{Heavy Metals}

The metals with an atomic number 22 to 92 in all groups from period 3 to 7 in the periodic table are regarded as Heavy metals. Some of the metals such as $\mathrm{Cu}, \mathrm{Zn}, \mathrm{Cd}, \mathrm{Pb}$, $\mathrm{Fe}, \mathrm{Cr}, \mathrm{Co}, \mathrm{Ni}, \mathrm{Mn}, \mathrm{Mo}, \mathrm{Se}$ are essential in trace quantities for the general well-being of living organism but an excess of these can be lethal. Kaur assessed the heavy metals concentration of $\mathrm{Pb}, \mathrm{Fe}, \mathrm{Zn}, \mathrm{Mn}, \mathrm{Cd}, \mathrm{Co}$, $\mathrm{Cu}, \mathrm{Cr}$ and $\mathrm{Ni}$ in the Yamuna river water flowing through the city of Delhi during two seasons viz. summer (May) and winter (January). Similar kind of studies have already carried out by several workers all over the world [28-33]. The concentration of heavy metals $(\mathrm{Cr}, \mathrm{Cu}, \mathrm{Ni}, \mathrm{Pb}$, and $\mathrm{Zn})$ in the study area, in the rivers Ganga and Yamuna on seven sampling stations at Allahabad using Atomic absorption Spectrophotometer indicated that the river is highly polluted Pandey et al. Anthropogenic activities and human interference in the natural ecosystem increases the load of heavy metals Kumar et al.

\section{Pesticides}

Pesticides are the major pollutants of the aquatic environment and their presence is of vital concern because of their potential toxicity towards vertebrates.

The microbial degradation of monocrotophos pesticides through different bacterial species viz. Arthrobacter atrocyaneus, Bacillus megaterium and Pseudomonas mendocina showed 80 to $90 \%$ degradation of monocrotophos at maximum initial concentration of $500 \mathrm{mg} / \mathrm{L}$ in synthetic medium within $48 \mathrm{~h}$. Deshpande extensively studied that the degradation of Dimethoate by several bacterial strains. Brevundimonas sp. showed 96\%, Bacillus sp. showed $94 \%$ while Klebsiella oxytoca showed $71 \%$ degradation of dimethoate pesticide within 12 days. The biological growth kinetics and bioconversion of Pseudomonas aeruginosa was investigated in batch process under aerobic condition for the degradation of $\mathrm{HCH}$ reported by Lodha et al. The bacterial isolate Pseudomonas aeruginosa (NCIM 2074) was used in bioremediation of chlorpyrifos at concentrations up to $50 \mathrm{mg} / \mathrm{l}$.

The unique approach for the biodegradation of organophosphorus pesticide (dimethoate) in aqueous media with effective microorganisms (EM) was investigated by Megeed and Nakieb. The research work of Pandey et al., revealed contamination of the surface sediments with several persistent organochlorine pesticides was found in the river Yamuna in Delhi. Endrin aldehyde, Endosulfan sulfate and DDT showed the 
highest percentage in all the three seasons. The total organochlorine pesticides level ranged from 157.71 - $307.66 \mathrm{ng} / \mathrm{g}$ in Premonsoon to $195.86-577.74 \mathrm{ng} / \mathrm{g}$ in Monsoon and 306.9 - $844.45 \mathrm{ng} / \mathrm{g}$ in the Post-monsoon season. The study demonstrates the pollution of the river with pesticide residues, but also the necessity of a continuous long-term monitoring of the affected environment. Kumar et al., [43] reported the maximum pesticide concentrations in water and sediments of the lakes were 4.12 (aldrin), 2.26 (endrin), 6.17 (pp'-DDT), $5.98 \mathrm{ng} \mathrm{mL} \mathrm{mL}^{-1}(\alpha$-endosulfan) and 167 (aldrin), 124 (endrin), 513 (pp'-DDT), 349 ng g-1 ( $\alpha$-endosulfan), respectively. The aldrin and endrin were absent at all the sites of the Yamuna. The maximum concentration of pp'-DDT and $\alpha$-endosulfan in river water was $3.37 \mathrm{ng} \mathrm{mL} \mathrm{mL}^{-1}$ and $3.55 \mathrm{ng} \mathrm{mL}-1$ and in sediments $525 \mathrm{ng} \mathrm{g}-1$ and $194 \mathrm{ng} \mathrm{g}^{-1}$ respectively.

\section{Current Status of Yamuna Water Quality}

The quality of river water can be assessed by the analysis of nutrients, chemistry, and biology. A healthy river is that which should contain at least $5 \mathrm{mg} / \mathrm{L}$ of Dissolved Oxygen (vital for the survival of marine life) and about $3 \mathrm{mg} / \mathrm{L}$ of Biochemical Oxygen Demand. Further the Pathogens (disease causing bacteria's) represented by the Faecal Coliforms counts should not exceed 500 per $100 \mathrm{~mL}$ of water. India River water qualities have been categories in five classes represented in Table-1. Yamuna River belongs to class $\mathrm{E}$. The Yamuna water quality is affected by the Swift urbanization and agricultural growth in Yamuna basin. Yamuna has six barrages which block the river flow and design the flowing situation. Usually most of the slush gets dumped at upstream of the barrages. These solid toxic substances that have settled, moves to downstream along with rapid and abrupt discharge of water from the barrages thereby increasing the river contamination. Central Pollution Control Board (CPCB) carries out regular checking and investigation of Water quality of Yamuna River since 1977. Degradation due to pollution has substantially decreased the ability of wetlands to provide enough amounts and also the water fulfilling the minimum standards. The constant dilapidation of wetlands, and more specifically the continued decline in water standards and quality, will result in further deterioration of human health especially for people in developing countries who are more vulnerable. This also affects aquatic life. The physicochemical parameters of water bodies like freshwater pond can be significantly changed by anthropogenic activities such as numerous farming practices and natural dynamics which subsequently disturb the water quality and quantity, biodiversity, capacity of the land to produce and even commotion in the of environmental equilibrium operating there.

\section{Techniques for Identification of Heavy Metals and Pesticides}

\section{Atomic Absorption Spectroscopy (AAS)}

AAS is an analytical method for quantification of around seventy different elements in solution or directly in solid samples. Procedure depends on atomization of elements by different atomization techniques like flame (FAAS), electrothermal (ETAAS), hydride or cold vapor.

In FAAS Two types of flame is used (i) air/acetylene flame, (ii) nitrous oxide/acetylene flame. Flame type depends on the analyte thermal stability and the compounds formed with flame concomitants. In air-acetylene flame and 
acetylene-nitrous oxide flame the temperature formed is around $2300^{\circ} \mathrm{C}$ and $3000^{\circ} \mathrm{C}$ respectively. The outline block diagram of FAAS and GFAAS is presented in Fig. 1. Basically source as hollow cathode lamp, Atomizer as flame or graphite furnace, wavelength selector as grating and detector as photomultiplier are used.

\section{Inductively Coupled Plasma Mass Spectroscopy (ICP-MS)}

ICP-MS is a multi-element technique in which plasma source is used to atomize the sample and the ions are detected by mass spectrometer. All elements are analyzed in a minute. There are several types of ICP-MS instruments; HRICP-MS (high resolution inductively coupled plasma mass spectrometry and MC-ICP-MS (multi collector inductively coupled plasma mass spectrometry). HR-ICP-MS, has magnetic as well as electric sector and separate and focus ions whereas MC-ICP-MS, are designed to perform high-precision isotope ratio analysis.

\section{Gas Chromatography Mass Spectroscopy (GCMS)}

GC-MS is a combination of two different distinctive features of gas-liquid chromatography and mass spectrometry for identification of different substances within a test sample. GC-MS has been widely heralded as a "gold standard" for the identification of forensic substance because it is used to perform a specific test. The specific test positively identifies the presence of a particular substance in a given sample. A non-specific test merely indicates that a substance falls into a category of substances. Although a non-specific test could statistically suggest the identity of the substance, this could lead to false positive identification.

GC-MS composed of two major building blocks: the gas chromatograph and the mass spectrometer. The gas chromatograph utilizes a capillary column which depends on the column's dimensions (length, diameter, film thickness) as well as the phase properties (e.g. 5\% phenyl polysiloxane). The difference in the chemical properties between different molecules in a mixture will separate the molecules as the sample travels the length of the column. The molecules are retained by the column and then elute (come off of) from the column at different times (called the retention time), and this allows the mass spectrometer downstream to capture, ionize, accelerate, deflect, and detect the ionized molecules separately. The mass spectrometer do this by breaking each molecule into ionized fragments and detect the fragments.

\section{Liquid Chromatography Mass Spectroscopy (LCMS)}

LCMS is a hyphenated technique which combines the separation power of HPLC with the detection power of mass spectrometry. Most instruments now atmospheric pressure ionisation (API) technique where solvent elimination and ionisation steps are combined in the source and take place at atmospheric pressure. When electron impact ionisation (EI) is the choice, the solvent elimination and ionisation steps are separate. The interface is a particle beam type, which separates the sample from the solvent, and allows the introduction of the sample in the form of dry particles into the high vacuum region. Electron impact is of interest for molecules which do not ionise with API technique, or when an electron impact spectrum is necessary, since it provides spectral information independent of the sample introduction technique (GC or LC, or direct introduction). 


\section{Bacterial Remediation of Major Pollutants from Waste Water}

The overall quality of the environment is linked inextricably to the quality of life on the Earth. Rapid industrialization and the progress in science and technology produce a large amount of raw sewage to nuclear waste which is dumped into the ecosystem thus posing a serious problem for survival of mankind itself on earth. During past time the wastes were disposed by traditional methods such as digging a hole and filling it with waste material. This approach of waste disposal was difficult to continue due to lack of new place every time to dump. Innovative technologies for waste disposal have evolved that use high-temperature incineration and chemical decomposition (e.g., base-catalyzed dechlorination, UV oxidation). Even though they can be very valuable at reducing wide a range of contaminants but at the same time have numerous drawbacks. Such methods are complex, uneconomical, and lack public acceptance. Several drawbacks in these methods have focused efforts towards harnessing modern day bioremediation process as a suitable alternative. Bioremediation is a microorganism mediated transformation or degradation of contaminants into nonhazardous or lesshazardous substances. The employability of different organisms like bacteria, fungi, algae, and plants for efficient bioremediation of pollutants has been reported by several investigators.

\section{Effect of Pesticides on Human Health}

Pesticides are congenitally toxic materials they are developed and used with the explicit intention to destroy or prevent the growth of life. The connection between pesticide exposure and common diseases affecting the public's health continues to strengthen causing more and more concern for individuals directly and indirectly exposed to pesticides. Farm workers are directly exposed to and work with pesticides on a daily basis. Diseases that are most linked to pesticide exposure are asthma, autism and learning disabilities, birth defects and reproductive dysfunction, diabetes, Parkinson's and Alzheimer's diseases, and several types of cancer. Acute or chronic low-levels inhalations of pesticides may increase the risk of developing asthma, exacerbate a previous asthmatic condition or even trigger asthma attacks by increasing bronchial hyper-responsiveness. Many pesticides are sensitizers or irritants capable of directly damaging the bronchial mucosa, and in turn making the airway very sensitive to allergens or other stimuli. Research shows that there is a significant association between cancer and pesticides used in agriculture and throughout the urban environment in homes, schools, and public places. The most common types of cancers that are associated with pesticide exposure are brain cancer, breast cancer, leukemia, lymphoma, prostate cancer and other cancers. A developing brain is much more susceptible to the toxic effects of chemicals than an adult brain. During development, the brain undergoes a highly complex series of processes at different stages. Research has shown that environmental toxicants, such as pesticides, at low levels of exposure can have subclinical effects - not clinically visible, but still important adverse effects, such as decreases in intelligence or changes in behavior. These include general developmental delays, attention deficit hyperactivity disorder (ADHD) and autism. A study by the National Institutes of Health (NIH) finds pesticide applicators with regular exposure to pesticides are at greater risk for type 2 diabetes. Applicators that had used certain insecticides more than 100 lifetime days nearly doubled their diabetes 
risk. The epidemiological and toxicological evidence is repeatedly identifying exposure to pesticides as significant adverse risk factors that contribute to Parkinson's disease. In a review of 40 epidemiological case-control studies from 1983-2005 published in the journal Environmental Health Perspectives, researchers evaluated the relationship between $\mathrm{PD}$ and pesticide exposure, finding sufficient evidence that an association exists and is strongest for exposure to herbicides and insecticides, and after long durations of exposure.

Continuous application of synthetic pesticides has also contributed to the extinction of useful organisms present in the soil. Besides contaminating the environment, including the soil, pesticide residues also affect useful organisms like earth worms, bees, spiders, plants and like to natural decay, which otherwise would have contributed towards preventing harmful pests. UNEP linked the effects of pesticides to "the level of oncological (cancer), pulmonary and haematological morbidity, as well as on inborn deformities and immune system deficiencies". Human health effects are caused by 1) Skin contact: handling of pesticide products, 2) Inhalation: breathing of dust or spray and 3) Ingestion: pesticides consumed as a contaminant on/in food or in water. Farm workers have special risks associated with inhalation and skin contact during preparation and application of pesticides to crops. However, for the majority of the population, a principal source is through ingestion of food which is contaminated by pesticides. Degradation of water quality by pesticide runoff has two principal human health impacts. The first is the consumption of fish and shellfish that are contaminated by pesticides; this can be a particular problem for subsistence fish economies that lie downstream of major agricultural areas. The second is the direct consumption of pesticide-contaminated water. WHO has established drinking water guidelines for 33 pesticides. Many health and environmental protection agencies have established "acceptable daily intake" (ADI) values that indicate the maximum allowable pesticide daily ingestion over a person's lifetime without appreciable risk to the individual. For example, Wang and Lin studying substituted phenols, tetrachloro hydroquinone, a toxic metabolite of the biocide pentachlorophenol, was found to produce significant and dose-dependent DNA damage. The harmful effects of pesticides are 1) Death of the organism, 2) Cancers, tumours and lesions on fish and animals, 3) Reproductive inhibition or failure, 4) Suppression of immune system, 5) Disruption of endocrine (hormonal) system, 6) Cellular and DNA damage, 7) Teratogenic effects (physical deformities such as hooked beaks on birds), 8) Poor fish health marked by low red to white blood cell ratio, excessive slime on fish scales and gills, etc., 9) Intergenerational effects (effects are not apparent until subsequent generations of the organism) and 10) Other physiological effects such as egg shell thinning. These effects are not necessarily caused solely by exposure to pesticides or other organic contaminants, but may be associated with a combination of environmental stresses such as eutrophication and pathogens. Pesticides are commonly found in water. The groundwater from some US and Canadian provinces has been reported to contain the residues of 39 pesticides and their metabolites. The calculation of level of allowable pesticide for water is made depending on the exposure of children and adults exposure; the children being 4 times more vulnerable to the pesticide toxicity than adults. Residues of pesticides that are "severely restricted" because of their serious effects on human health were also found in significant 
quantities in the water sources. The pesticide residues exerting serious effects on human health enter the water supply through leaching from soil into ground water.

\section{Effect of Heavy Metals on Human Health}

\section{Arsenic}

Arsenic a metalloid, rarely found as a free element in the natural environment, but more commonly as a component of sulphurcontaining ores in which it occurs as metal arsenides. Arsenic is extensively distributed in natural waters and is often associated with geological sources, but in some locations anthropogenic inputs, such as the use of arsenical insecticides and the combustion of fossil fuels, can be extremely important additional sources. Acute arsenic poisoning is infamous for its lethality, which stems from arsenic's destruction of the integrity of blood vessels and gastrointestinal tissue and its effect on the heart and brain Arsenic has been reported to vary in: blood, from 1.5 to $2.5 \mathrm{~g} \mathrm{~L}-1$; hair, from 0.25 to $0.88 \mathrm{~g} \mathrm{~L}-1$; and urine the average concentrations are between 20 and $50 \mathrm{~g} \mathrm{L-1}$. In humans arsenic toxicity occurs due to ingestion of As containing powders or solutions accidentally, suicide, homicide, or consumption of contaminated food or drinking water. Arsenic has been reported to be associated with hypertension and serious impacts on the cardiovascular system, and even hepatic damage at high doses It has a suppressive effect on spermatogenesis and gonadotrophin and testosterone release in rat. There is correlation between arsenic exposure and diabetes mellitus (type II). Inorganic arsenic is considered carcinogenic and is related mainly to lung, kidney, bladder, and skin disorders. The toxicity of arsenic in its inorganic form has been known for decades under the following forms: acute toxicity, subchronic toxicity, genetic toxicity, developmental and reproductive toxicity, immunotoxicity, biochemical and cellular toxicity, and chronic toxicity. However, the accumulation of arsenic in rice field soils and its introduction into the food chain through uptake by the rice plant is of major concern mainly in Asian countries. The JECFA established a PTWI for inorganic arsenic as $0.015 \mathrm{mg} / \mathrm{kg}$ body weight. Organo-arsenic intakes of about $0.05 \mathrm{mg} / \mathrm{kg}$ body weight/day seemed not to be associated to hazardous effects.

\section{Cadmium}

Cadmium is a accumulative toxicant and carcinogenic which adversely affects kidneys, disturbs bone metabolism and deforms reproductive tract as well as endocrine system and generates various toxic effects in the body. In particular, the loss of calcium caused by cadmium's effect on the kidney can be severe enough to lead to weakening of the bones. "Itaiitai" disease, an epidemic of bone fractures in Japan from gross cadmium contamination of rice stocks, has recently been shown to happen in more subtle fashion among a general community living in an area of relatively modest cadmium contamination. An exposure to cadmium enhances calcium excretion thus causes skeletal demineralization and probably leading to increases in bone fragility and risk of fractures. Cadmium exposure, during human pregnancy, leads to reduced birth weights and premature birth. Occupational levels of cadmium exposure are a risk factor for chronic lung disease (through airborne exposure) and testicular degeneration and are still under investigation as a risk factor for prostate cancer. Due to excessive accumulation of cadmium, other damages have been observed include reproductive, and development toxicity, hepatic, haematological and immunological effects. 
The Joint FAO/WHO has recommended the PTWI as $0.007 \mathrm{mg} / \mathrm{kg}$ bw for cadmium. The EPA maximum contaminant level for cadmium in drinking water is $0.005 \mathrm{mg} / \mathrm{L}$ whereas the WHO adopted the provisional guideline of $0.003 \mathrm{mg} / \mathrm{L}$.

\section{Lead}

Lead is the archetype metal toxin in terms of its many sources and pathways for exposure, global distribution, ability to accumulate in the body, and impact on human health even at low levels of exposure. Lead as a toxicologically relevant element has been brought into the environment by man in extreme amounts, despite its low geochemical mobility and has been distributed worldwide. Lead can contaminate water and consequently enter the aquatic food chains.

Children under 6 years are especially susceptible to the adverse effects of $\mathrm{Pb}$, as the blood-brain barrier is not yet fully developed in young children, hematological and neurological adverse effects of $\mathrm{Pb}$ occur at lower threshold levels than in adults. $\mathrm{Pb}$ has effects on erythropoiesis and haem biosynthesis. Chronic $\mathrm{Pb}$ intoxication in adults resulted in to anemia, some types of cancer, reproductive harm in males while in young children hormonal imbalance of metabolite of vitamin D, namely 1, 25dihydroxy-vitamin D, drop in IQ.

Table.1 Different Classes Defining the Water Quality

\begin{tabular}{|l|l|}
\hline Classes & \multicolumn{1}{|c|}{ Water Quality } \\
\hline A & $\begin{array}{l}\text { River water fit for drinking after proper disinfection with } \\
\text { the addition of chlorine or bleaching powder }\end{array}$ \\
\hline B & River water is fit only for bathing \\
\hline C & $\begin{array}{l}\text { The River water is fit for drinking only after proper } \\
\text { treatment (screening to remove physical matters or } \\
\text { particulate such as paper, plastic, etc. }\end{array}$ \\
\hline D & $\begin{array}{l}\text { Under this class the river water is fit only for fish and } \\
\text { wildlife }\end{array}$ \\
\hline E & $\begin{array}{l}\text { River water is suitable only for industrial cooling, } \\
\text { irrigation, etc. }\end{array}$ \\
\hline
\end{tabular}

Fig1 Literature Review (Synthesized form)

\begin{tabular}{|l|}
\hline \multicolumn{1}{|c|}{$\begin{array}{c}\text { Physico-chemical } \\
\text { parameters }\end{array}$} \\
\hline - Ozha 1998 \\
- Kumar et al 1998 \\
- Mishra and \\
Tripathi, 2000 \\
- Joshi and \\
Sharma, 2002 \\
-Shrivastava et al, 2010 \\
- Raghav et al, 2014 \\
\\
\end{tabular}

\begin{tabular}{|l|}
\hline \multicolumn{1}{|c|}{ Heavy metals } \\
\hline -Sharma and \\
Rehman, 2009 \\
- Kaur, 2012 \\
-Sehgal et al., 2012; \\
-Chakrabarty and \\
Sarma, 2011; \\
-Puthiyasekar et al., 2010; \\
-Dan'azumi and \\
Bichi, 2010; \\
-Ahmed et al., 2010; \\
-Pandey et al., 2010 \\
-Pandey et al, 2013 \\
-Kumar et al, 2013 \\
\hline
\end{tabular}

\begin{tabular}{|l|}
\hline Pesticides \\
\hline -Mishra et al., 2006 \\
- Bhadbhade, 2001 \\
- Deshpande, 2002 \\
- Lodha et al, 2007 \\
- Geetha and \\
fulekar, 2008 \\
-Megeed and \\
Nakieb, 2008 \\
-Pandey et al, 2011 \\
- Kumar et al, 2014 \\
\end{tabular}


Table.2 Techniques for Determination of Heavy Metal Ions and Pesticide Residues

\begin{tabular}{|c|c|c|}
\hline Techniques & Heavy metals/Pesticides & References \\
\hline $\begin{array}{c}\text { Flame Atomic Absorption Spectrophotometer } \\
\text { (FAAS-Perkin Elmer, Analyst 100) }\end{array}$ & Lead, Cadmium & $\begin{array}{l}\text { Sharma and } \\
\text { Prasad [56] }\end{array}$ \\
\hline $\begin{array}{c}\text { Air acetylene Atomic Absorption } \\
\text { Spectrophotometer AA, 220G (Varian Pvt. } \\
\text { Ltd. Hyderabad) }\end{array}$ & $\begin{array}{c}\text { Chromium, Copper, Iron, Nickel, } \\
\text { Lead, Zinc }\end{array}$ & $\begin{array}{l}\text { Pandey et al } \\
{[34]}\end{array}$ \\
\hline $\begin{array}{l}\text { Atomic Absorption Spectrophotometer } \\
\text { (Model-3110) using Air Acetylene Flame }\end{array}$ & Copper, Lead, Cadmium, Zinc & Jain [57] \\
\hline $\begin{array}{l}\text { Atomic Absorption Spectrophotometer } \\
\text { Spectra AA } 220 \text { G (Varian GTA 110) }\end{array}$ & Copper, Zinc, Nickel, Lead & $\begin{array}{c}\text { Kumar et al } \\
\text { [35] }\end{array}$ \\
\hline $\begin{array}{l}\text { Flame Atomic Absorption Spectrometer } \\
\text { (Analytik Jena-Vario-6) }\end{array}$ & Arsenic, Mercury & $\begin{array}{l}\text { Singh et al } \\
{[58]}\end{array}$ \\
\hline Flame Atomic Absorption Spectrometer & $\begin{array}{l}\text { Chromium, Manganese, Iron, } \\
\text { Copper, Nickel, Cobalt, Zinc, } \\
\text { Cadmium, Lead }\end{array}$ & $\begin{array}{c}\text { Mahmoud et al } \\
{[59]}\end{array}$ \\
\hline $\begin{array}{l}\text { Inductively Coupled Plasma Mass } \\
\text { Spectroscopy (ICP-MS) }\end{array}$ & $\begin{array}{l}\text { Lead, Zinc, Iron, Manganese, } \\
\text { Cadmium, Cobalt }\end{array}$ & Kaur, [27] \\
\hline $\begin{array}{c}\text { Inductively Coupled Plasma Quadrupole } \\
\text { Mass Spectroscopy (ICP-Q-MS) }\end{array}$ & $\begin{array}{c}\text { Aluminium, Arsenic, Lead, } \\
\text { Cadmium, Zinc, Cobalt, Vanadium }\end{array}$ & $\begin{array}{l}\text { Voica et al } \\
{[60]}\end{array}$ \\
\hline ICP-MS (Agilent 7300) & $\begin{array}{l}\text { Nickel, Arsenic, Cadmium, } \\
\text { Selenium, Mercury, Cobalt }\end{array}$ & Reddy et al \\
\hline ICP/MS (Agilent technologies 7500 series) & $\begin{array}{c}\text { Lead, Bismuth, Manganese, } \\
\text { Chromium, Cobalt, Nickel, Copper, } \\
\text { Cadmium }\end{array}$ & $\begin{array}{c}\text { Malassa et al } \\
{[62]}\end{array}$ \\
\hline GCMS (GC/MS model QP 2010 Shimadzu) & $\begin{array}{l}\text { Glyophosphate, Methoxy fenozide, } \\
\text { Fenoxycarb, Flumioxazin, } \\
\text { Crotoxyphos, Piperonylbutoide }\end{array}$ & $\begin{array}{l}\text { Hussain and } \\
\text { Siddique [63] }\end{array}$ \\
\hline Gas liquid Chromatography & Dimethoate & $\begin{array}{l}\text { Megeed and } \\
\text { Nakieb }[41]\end{array}$ \\
\hline $\begin{array}{l}\text { Gas Chromatograph (Perkin Elmer } \\
\text { Instruments, Autosystem XL GC) }\end{array}$ & $\begin{array}{l}\text { Organochlorine [Heptachlor, Aldrin, } \\
\text { DDD, DDE, Endosulfan 2, } \\
\text { Methoxychlor] }\end{array}$ & $\begin{array}{l}\text { Pandey et al } \\
{[42]}\end{array}$ \\
\hline LCMS (Perkin- Elmer 200 Series) & $\begin{array}{c}\text { Malathion, Propenophos, } \\
\text { Quinolphos, Triazophas, Carbaryl, } \\
\text { Hexaconazole }\end{array}$ & $\begin{array}{l}\text { Sabale et al } \\
{[64]}\end{array}$ \\
\hline LCMS & $\begin{array}{l}\text { Alachlor, buprofezin, chlorpyriphos, } \\
\text { chlorfenvinphos, diuron, fenthion, } \\
\text { hexythiazox, isoproturon, malathion, } \\
\text { tolclofos methyl, prochlora, imazalil, } \\
\text { abamectin, diazinon, atrazine, } \\
\text { simazine) }\end{array}$ & $\begin{array}{c}\text { Giordano et al } \\
{[65]}\end{array}$ \\
\hline LCMS & $\begin{array}{l}\text { (carbofuran, clomazone, } \\
\text { tebuconazole }\end{array}$ & $\begin{array}{l}\text { Caldas et al } \\
{[66]}\end{array}$ \\
\hline
\end{tabular}


Table.3 List of Bacterial Isolates used for Remediation of Various Pollutants

\begin{tabular}{|c|c|c|}
\hline Bacterial Species & Toxic Pollutants & References \\
\hline $\begin{array}{l}\text { Pseudomonas, Neisseria, } \\
\text { Moraxella, Acinetobacter }\end{array}$ & DDT & Carrillo-Pérez E et al [70] \\
\hline $\begin{array}{l}\text { Pseudomonas spinosa, } \\
\text { Pseudomonas aeruginoa } \\
\text { Burkholderia, } \\
\text { Staphylococcus }\end{array}$ & Endosulfan & $\begin{array}{l}\text { Lee et al [71] } \\
\text { Hussain et al [72] } \\
\text { Kumar and Philip [73] }\end{array}$ \\
\hline $\begin{array}{l}\text { Pseudomonas, Bacillus, } \\
\text { Aerobacter, Micrococcus } \\
\text { and Burkholderia }\end{array}$ & Dieldrin and Endrin & Matsumoto et al [74] \\
\hline $\begin{array}{l}\text { Pseudomonas, } \\
\text { Burkholderia, } \\
\text { Flavobacterium and } \\
\text { Vibrio }\end{array}$ & $\mathrm{HCH}$ & Murthy et al [75] \\
\hline $\begin{array}{l}\text { Proteus, Vibrio, Yersinia } \\
\text { Serratia }\end{array}$ & Tetrachlorvinphos & Ortiz-Hernández et al [76] \\
\hline Pseudomonas & $\begin{array}{l}\text { Cypermethrin, Oxyfluorfen, } \\
\text { Chlorpyrifos, } \\
\text { Iprodione(Fungicide), } \\
\text { Atrazine }\end{array}$ & $\begin{array}{l}\text { Boricha and Fulekar [77] } \\
\text { Fulekar [78] } \\
\text { Fulekar and Geetha [40] } \\
\text { Mohamed et al [79] }\end{array}$ \\
\hline Bacillus & $\begin{array}{ll}\text { Lindane, } & \text { Endosulfan, } \\
\text { Oxyfluorfen } & \end{array}$ & \begin{tabular}{|l|} 
Benimeli et al, [80] \\
Kumar and Philip, [73] \\
Pesce and Wunderlin, [81]
\end{tabular} \\
\hline $\begin{array}{l}\text { Pseudomonas, } \\
\text { Rhodococcus, } \\
\text { Arthrobacter, } \\
\text { Streptomyces }\end{array}$ & Atrazine & $\begin{array}{l}\text { Hernandez et al, [82] } \\
\text { Fujii et al, [83] } \\
\text { Vibber et al, [84] } \\
\text { Martinez et al [85] } \\
\text { Shelton et al., [86] }\end{array}$ \\
\hline Pseudomonas putida & $\begin{array}{l}\begin{array}{l}\text { Cadmium, Lead, Zinc, } \\
\text { Copper }\end{array} \\
\end{array}$ & $\begin{array}{l}\text { Pardo et al., [87] } \\
\text { Hussein et al.,[88] }\end{array}$ \\
\hline $\begin{array}{l}\text { Stenotrophomonas } \\
\text { maltophilia, } \\
\text { Exiguobacterium sp., } \\
\text { Pantoea sp., and } \\
\text { Aeromonas sp } \\
\text { Bacillus circulans and } \\
\text { Bacillus megaterium } \\
\text { B. cereus }\end{array}$ & Chromium & $\begin{array}{l}\text { Alam and Ahmad [89] } \\
\text { Srinath et al. [90] } \\
\text { Tripathi [91] }\end{array}$ \\
\hline $\begin{array}{l}\text { Brevibacterium sp. } \\
\text { Micrococcus } s p .\end{array}$ & Lead & $\begin{array}{l}\text { Andreoni et al., [92] } \\
\text { Zaied et al., [93] }\end{array}$ \\
\hline
\end{tabular}


Table.4 Clinical Aspects of Chronic Toxicities

\begin{tabular}{|l|l|l|}
\hline \multicolumn{1}{|c|}{ Metals } & \multicolumn{1}{|c|}{ Target Organs } & \multicolumn{1}{|c|}{ Clinical effects } \\
\hline Arsenic & $\begin{array}{l}\text { Pulmonary Nervous } \\
\text { System, Skin }\end{array}$ & $\begin{array}{l}\text { Perforation of Nasal Septum, Respiratory } \\
\text { Cancer, Peripheral Neuropathy: Dermatomes, } \\
\text { Skin, Cancer }\end{array}$ \\
\hline Cadmium & Renal, Skeletal Pulmonary & $\begin{array}{l}\text { Proteinuria, Glucosuria, Osteomalacia, } \\
\text { Aminoaciduria, Emphysemia }\end{array}$ \\
\hline Chromium & Pulmonary & $\begin{array}{l}\text { Ulcer, Perforation of Nasal Septum, } \\
\text { Respiratory Cancer }\end{array}$ \\
\hline Manganese & Nervous System & Central And Peripheral Neuropathies \\
\hline Lead & $\begin{array}{l}\text { Nervous } \\
\text { System,Hematopoietic } \\
\text { System, Renal }\end{array}$ & $\begin{array}{l}\text { Encephalopathy, Peripheral Neuropathy, } \\
\text { Central Nervous Disorders, Anemia. }\end{array}$ \\
\hline Nickel & Pulmonary, Skin & Cancer, Dramatis \\
\hline Tin & $\begin{array}{l}\text { Nervous, Pulmonary } \\
\text { System }\end{array}$ & $\begin{array}{l}\text { Central Nervous System Disorders, Visual } \\
\text { Defects And EEG Changes, Pneumoconiosis. }\end{array}$ \\
\hline Mercury & Nervous System, Renal & Proteinuria \\
\hline
\end{tabular}

Source: Mahurpawar,[147]

Fig.2 FAAS and GFAAS Block Diagram

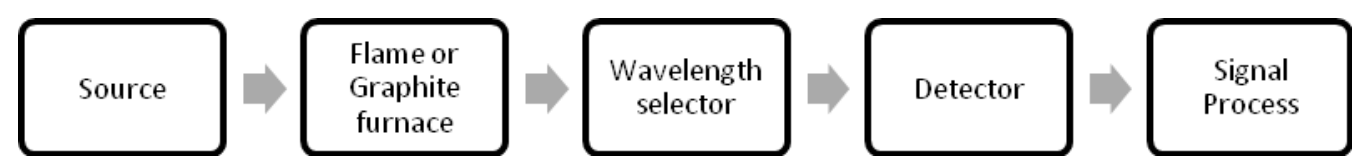

Fig.3 ICP-MS Block Diagram

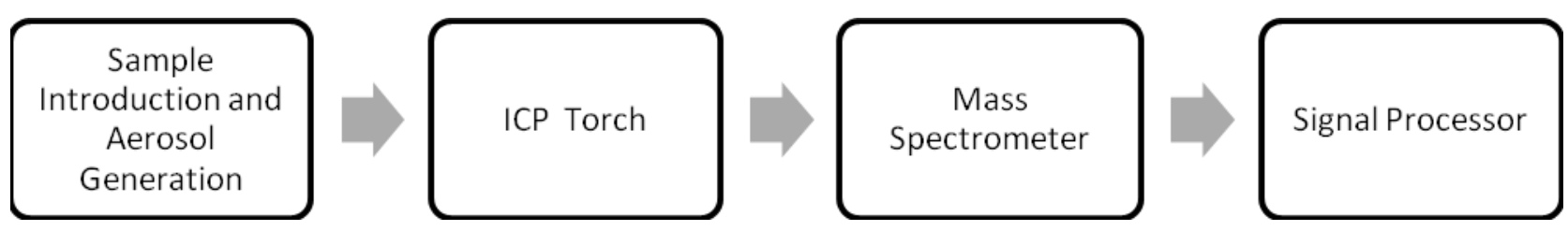

Fig.4 Block Diagram of GCMS

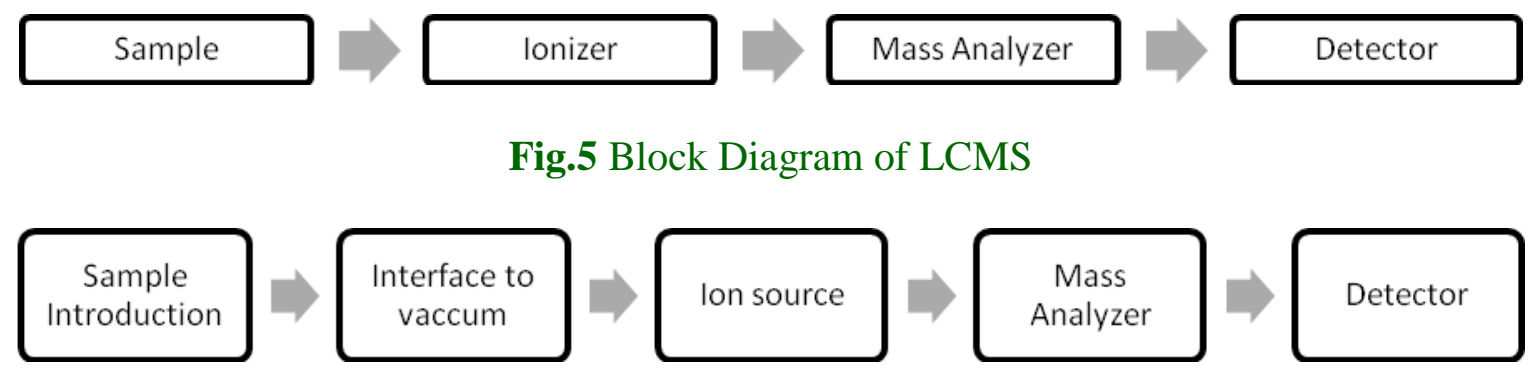


In humans, about 20 to $50 \%$ of inhaled, and 5 to $15 \%$ of ingested inorganic lead is absorbed. In contrast, about $80 \%$ of inhaled organic lead is absorbed, and ingested organic $\mathrm{Pb}$ is absorbed readily. Once in the bloodstream, lead is primarily distributed among blood, soft tissue, and mineralizing tissue. The bones and teeth of adults contain more than $95 \%$ of the total body burden of lead. Children are particularly sensitive to this metal because of their more rapid growth rate and metabolism, with critical effects in the developing nervous system. The Joint FAO/ World Health Organization Expert Committee on Food Additives (JECFA) established a provisional tolerable weekly intake (PTWI) for lead as 0.025 $\mathrm{mg} / \mathrm{kg}$ body weight (bw). The WHO provisional guideline of $0.01 \mathrm{mg} / \mathrm{L}$ has been adopted as the standard for drinking water.

\section{Mercury}

Mercury is organomercurial in the form of methylmercury which have toxicological characteristics. Minamata disease name given after of methylmercury in seafood in Minamata and Niigata in Japan in the 19501960 's, caused the death of thousands of people. Mercurial fungicides treated wheat seeds cause poisoning and death of 5,000 to 50,000 people. Tokuomi et al., were the first to describe the symptoms of methylmercury poisoning. Thus, the symptoms were named the Hunter-Russell syndrome. A few studies reflect that even minor increases in methylmercury exposures can cause harmful effects on the cardiovascular system, blisters in the upper gastrointestinal tract, vomiting, abdominal pain, constipation and gastritis. Renal toxicity of organic forms expressed by glomerulonephritis with proteinuria (glomerular and tubular) and nephritic syndrome. Elemental $\mathrm{Hg}$ can be oxidized to $\mathrm{Hg}^{2+}$, which accumulates preferentially in the kidneys. The increased excretion of low molecular weight proteins demonstrated at low-level exposure, and related to damage to the renal tubes. It is a potent neuro-toxin to human due to their ability to cross the bloodbrain barrier. It is absorbed in the gastrointestinal track, immediately entering the blood stream. It readily passes the placental barrier affecting the developing nervous system of the foetus.

Continuous exposure conditions to elemental $\mathrm{Hg}$ can lead to its accumulation in the thyroid. The acute exposure to elemental $\mathrm{Hg}$ vapors can cause "pink disease" or acrodynia. Modest levels of occupational mercury exposure, as experienced, for example, by dentists, have been associated with measurable declines in performance on neurobehavioral tests of motor speed, visual scanning, verbal and visual memory, and visuomotor coordination. Contrary to some opinions expressed in the popular media, however, evidence from well-conducted studies is lacking that the small amount of mercury released from dental amalgams during chewing is capable of causing significant illnesses, such as mutliple sclerosis, systemic lupus, or chronic fatigue syndrome. Special note should be taken of dimethylmercury---a "supertoxic, superdangerous" compound that can penetrate through latex gloves, as well as skin. Exposure to only a few drops can lead to central nervous system degeneration and death but the compound is luckily encountered only in specialized laboratories. Because of the extreme health effects associated with mercury exposure, the current standards for drinking water were set by EPA and WHO at the very low levels of $0.002 \mathrm{mg} / \mathrm{L}$ and $0.001 \mathrm{mg} / \mathrm{L}$, respectively.

In conclusion, Water is a key resource for numerous human activities, and rivers are a main source of water in several parts of India. Unfortunately, rivers have become a 
major sink of wastes due to several toxic pollutants flowing into them. The water quality of Yamuna has worsened and disgustingly polluted due to municipal and industrial waste water disposal. According to the latest status of water quality in India the Yamuna water quality has been described as the worst affected and was placed seventh on the list of rivers with highest Biochemical Oxygen Demand (CPCB). The total BOD content in the Yamuna was $93 \mathrm{mg} / \mathrm{L}$, while the permissible level is $3 \mathrm{mg} / \mathrm{L}$ and the level of Dissolved Oxygen was less than $4 \mathrm{mg} / \mathrm{L}$ due to discharge of untreated and partially treated wastewater. The River water management is an important area among various natural resource management policies and in order to be more efficient, it requires public intervention through proper institution and an action plan approach. The improvement and maintenance of water quality of river Yamuna are the need of the hour due to the variety of problems related to the water quality of Yamuna.

\section{References}

1. Daniel, P.H. Investing in Tomorrow's Liquid Gold,”. http://finance. yahoo.com/ columnist/article/ trenddesk/" 19April 2006; 3748.

2. Kumar, N. A View on Freshwater environment. Ecol. Env \& Cons. 1997; 3:3-4.

3. Vollenweidre, R.A. Scientific fundamental of the eutrophication of lakes and flowing waters with special reference to nitrogen and phosphorus, as factoring eutrophication. O. E C. D. Paris, 1986.

4. Hooper, F.F. Eutrophication causes consequences and correctives. In the Proceeding of National Academy of Sciences, Washington, D.C. 1969.
5. Milway, C. P. Educational in large lakes and impoundments. In the Proceeding of Upplasale Symposium, DECD, Paris. 1969.

6. Olimax, T, Sikorska U. Field experiment on the effect of municipal sewage on macrophytes and epifauna in the lake littoral. Bull. Acad. Pol. Sc. Clii, 1975; 23: 445-447.

7. CPCB, 2006. Water Quality Status Of Yamuna River (1999- 2005), Central Pollution Control Board, Ministry of Environment \& Forests, Assessment and Development of River Basin Series: ADSORBS/41/2006-07

8. United Nations Intergovernmental Panel on Climate Change- Fifth Assessment Report; Climate Change: Impacts, Adaptation and Vulnerability, Yokohoma, Japan 2014.

9. Asha Latha P. and Sandeep Reddy S. Review on Bioremediation- Potential Tool for Removing Environmental Pollution, Int. $J$ of Basic and Appl. Chem. Sci., 2013; ISSN : 2277- 2073

10. Viswanathan, P.N. Environmental toxicology in India. Biol. Mem., 1985; 11: 88-97.

11. Deflora, S., L. Vigano, F. Dagoslini, A. Camorirano, M. Bagnasco, C. Bennicelli, F. Melodia and A. Arillo Multiple genotoxicity Biomarkers in fish exposed in situ to polluted river water. Mutat. Res.1993; 319: 167177.

12. Kuroda, K., Y. Yamagachi and G. Endo. Mitotic toxicity, sister Chromatid exchange and rec assay of pesticides. Arch. Environ. Contam. Toxicol.1992; 23: 13- 18.

13. Rehana, Z., A. Malik and M. Ahmad. Mutagenic activity of the Ganges water with special reference to pesticide pollution in the River 
between kachla to kannauj (up). India. Mutat. Res. 1995; 343: 137144.

14. Kale, S.P., N.B.K. Murthy and K. Raghu,. Effect of carbofuran, Carbaryl and their metabolites in the growth of Rhizobium sp. and Azotobacter chroococcum. Bull. Environ. Contam. Toxicol., 1989; 42: 769-772.

15. Tu, C.M. Effects of herbicides and fumigants on microbial Activities in soil.Bull. Environ. Contam. Toxicol. 1994; 53: 12- 17.

16. Koshy, M.; Nayar, T.V. Water quality aspects of River Pamba. Pollut. Res. 1999; 18: 501-510.

17. Saxena K. K. and Chauhan R. S. S. PhysicoChemical aspects of pollution in river Yamuna at Agra. Pollen. Res. 1993; 12: 101-104.

18. Central Pollution Control Board (CPCB) 1996-1997.Water quality and Statistics, Monitoring of Indian National Aquatic Resources series/MMARS/13/1998-99.

19. Reuters News Service, Netherlands, 1999, 30" November.

20. Ozha, D.D. Water and its formidable pollution: Needs immediate attention. Res. J. Chem. Environ. 1998; 2: 63-64

21. Kumar, A., Kumar, R., Sharma, A., Gangal, S.V., Gangal, V. and Makhijani, S.D. Biodegradable organic matter in industrial waste water as determined by formulated microbial mixture. J. Environ. Biol.1998; 19:67-72.

22. Mishra, B.P., and Tripathi, B.D. Sewage quality analysis: Pollutants removal efficiency of a sewage treatment plants. J. Ind. Poll. Cont. 2000; 16:239-251.

23. Joshi, P.K. and Sharma, N. Bioremediation of sewage through bacterial inoculation under laboratory conditions In: 43 Annual Conference of Association of Microbiologist of India. C.C.S. Haryana Agricultuer University. Hisar. Dec 2002; 11-13,183.

24. Shrivastava, J.N, Singh A, Kumar V. Green Biotechnology of Effective microbes in Bioremediation of waste water, J. Geobios, 2010; 236-237

25. Raghav N, Shrivastava J.N. Remediation of Yamuna River water in city of Taj by Bacterial Consortium. Int. J. Pure App. Biosci. 2014; 2 (2): 249-253

26. Sharma A, Rehman M.B. Laboratory scale approach. Ind. J of Microbio. 2009; 48: 142-146.

27. Kaur S. Assessment of Heavy Metals in Summer and Winter Seasons in River Yamuna Segment Flowing through Delhi, India. J of Environ. and Eco. 2012; 3: 149-165

28. Sehgal, M., Garg, A. Suresh, R. and Dagar, P. Heavy metal contamination in the Delhi segment of Yamuna basin. Environ. Monitor. Assess. 2012; 184:1181-1196.

29. Chakrabarty, S and Sharma H.P. Heavy metal contamination of drinking water in Kamrup district, Assam, India. Environ. Monitor. and Assess. 2011; 179:479-486.

30. Puthiyasekar, C., Neelakantan, M. A., \& Poongothai S. Heavy metal contamination in bore water due to industrial pollution and polluted and non polluted sea water intrusion in Thoothukudi and Tirunelveli of South Tamil Nadu, India. Bull. of Environ. Contam. and toxicol., 2010; 85: 598-601.

31. Dan'azumi, $\mathrm{S}$ and Bichi, M.H. Industrial pollution and heavy metal profile of Challawa river in Nigeria, J of Appl. Sci. in Environ. Sani. 2010; 5: 23-29. 
32. Ahmed, M.K., Bhowmik, A.C., Rahman, $S$ and Haque, M.R. Heavy metal concentration in water, sediments and freshwater mussels and fishes of the river Shitalakhya, Bangladesh. Asian J of Water, Environ. and Poll. 2010; 7: 77-90.

33. Pandey, J. Shubhashish, P.K. \& Pandey, R. Heavy metal contamination of Ganga river at Varanasi in relation to atmospheric deposition. Trop. Eco. 2010; 51: 365-373.

34. Pandey A, Ramteke P.W and Verma O.P. Evaluation of heavy metals loading of rivers Ganga and Yamuna In. Int. J Pharm Bio Sci. 2013; 4: 1410-1417

35. Kumar R, Gupta A.K, Tripathi R.M, Chattree A. Monitoring Heavy metals Contamination in Yamuna River for its toxicity level in water, sediments and fish. J of Environ. Sci, Toxicol. and Food. Technol. 2013; 5: 113-118.

36. Mishra S, Kishan J, Verma K. Monitoring organophosphorus pesticides and their degradation products formed by Fenton's Reagent using solid phase extraction gas chromatography mass spectroscopy. Int. J. of Environ. And Poll. 2006; 27: 1-3.

37.Bhadbhade BJ. Microbial degradation of an organophosphorus pesticideMonocrotophos. Ph.D Thesis in Microbiology, University of Pune 2001.

38. Deshpande NM. Biodegradation of Dimethoate- a carbamate group of organophosphorus insecticides. Ph.D thesis in Microbiology, University of Pune 2002.

39. Lodha B, Bhat P, Kumar M. S, Vaidya A. N, Mudliar S, Killedar D. J. and Chakrabarti T. Bioisomerization kinetics of $\gamma-\mathrm{HCH}$ and biokinetics of
Pseudomonas aeruginosa degrading technical HCH. J. Biochem. Eng. 2007; 35: 12-19.

40. Geetha M, Fulekar MH. Bioremediation of pesticides in surface soil treatment unit using microbial consortia. African $J$ of Environ. Sci. and Technol. 2008: 2: 36-45.

41. Meeged A A, Nakieb AF. Bioremediation of Dimethoate by Effective Microorganisms in water. Terrest.and Aquat. Environ. Toxic. 2008; 2:1-4.

42. Pandey P, Khillare K.S, Kumar K. Assessment of Organochlorine pesticides residues in the surface sediments of River Yamuna in Delhi, India. J of Environ. Protect. 2011; 2: 511-524.

43. Kumar R, Gupta B, Gupta H, Rani M. Distribution of Persistent Organic Pollutants in Urban Aquatic Systems. Int. $J$ of Sci. Res. in Environ. Sci, 2014; 2: 233-243.

44. Misra A.K. A River about to Die: Yamuna. J. Water Res. and Protect. 2010; 2: 489-500.

45.Hindu, "Delhi reduces Yamuna to a sewage drain," New Delhi. http://www.hinduonnet.com/thehind u/2002 /06/25/ stories/ $2002062506380400 . h t m 2002$.

46. http://edugreen. teri.res.in/ explore/maps /water.htm, (2014)

47. Mushini V.S.R., Vaddi D.R. and Bethapudi S.A.A., Assessment of Quality of Drinking Water at Srikurmam in Srikakulam District, Andhra Pradesh, India, I. Res. J. Environment Sci., 2012; 1: 13-20.

48. Vincy M.V., Brilliant Rajan and Pradeep Kumar A.P., Water Quality Assessment of a Tropical Wetland Ecosystem with Special Reference to Backwater Tourism, Kerala, South India, International Research Journal 
of Environment Sciences, ISSN 2319-1414, 2012; 1: 62-68.

49. Pathak Neelam B. and Mankodi P.C., Hydrological status of Danteshwar pond, Vadodara, Gujarat, India, Int. Res. J. Environment Sci., ISSN 2319-1414, 2013; 2: 43-48.

50. Patil Shilpa G., Chonde Sonal G., Jadhav Aasawari S. and Raut Prakash D., Impact of Physico-Chemical Characteristics of Shivaji University lakes on Phytoplankton Communities, Kolhapur, India, Res J. Recent Sci., ISSN 2277-2502, 2012: 1: 56-60.

51. Baysal A, Ozbek $\mathrm{N}$ and Akman S. Determination of Trace Metals in Waste Water and Their Removal Processes. Waste Water - Treatment Technologies and Recent Analytical Developments. 2013; 145-171. http://dx.doi.org/10.5772/52025.

52. Skoog, D. A., Holler, F. J., \& Nieman, T. A. Principles of instrumental analysis, Philadelphia, Saunders College Pub 1998.

53.D.R. Jenke, "Chromatographic Method Validation: A review of Current Practices and Procedures. I. General Concepts and Guidelines", J. Liq. Chrom. and Rel.Technol., vol. 19 (1996), pp. 719-736. SWGDRG, Quality Assurance/General Practices Recommendations, 2008.

54. International Organization for Standardization, ISO 9000:2000 Quality management systemsFundamentals and vocabulary.

55. Alon, T.; Amirav, A."Isotope Abundance Analysis Method and Software for Improved Sample Identification with the Supersonic GC-MS". Rapid Communications in Mass Spectrometry 2006; 20: 2579 2588.

56. Sharma and Prasad. Accumulation of
Lead and Cadmium in soil and vegetable crops along Major highways in Agra (India). E-Journal of Chemistry, 2010; 7: 1174-1183.

57. Jain C.K. Metal fractionation study on bed sediments of River Yamuna, India. Water Res.2004; 38: 569-578.

58.Singh N, Chauhan S, Singh K, Saud T, Saxena M, Soni D, Mandal KT, Bassin KJ, Gupta K.P. Determination of arsenic and mercury metals in suspended particulate matter by flame/flameless atomic absorption spectrometer. Atmos. Poll. Res. 2010; 1: 112-117.

59. Mahmoud, M. E., Kenawy, I. M. M., Hafez, M. A. H., \& Lashein, R. R. Remov- al, preconcentration and determination of trace heavy metal ions in water samples by AAS via chemically modified silica gel N-(1carboxy-6-hydroxy)

benzylidenepropyl- amine ion exchanger. Desalination, 2010; 250: 62-70.

60. Voica C, Dehelean A, Iordache A, Geana I. Method validation for determination of metals in soils by ICP-MS. Rom. Reports. in Phy, 2012; 64: 221-231.

61. Reddy Rami Y.V, Reddy Hanuman V, Prasad P.M.N, Ramana Reddy A.V. Determination of heavy metals in surface and groundwater in and around Tirupati, Chittor (Di), Andhra Pradesh, India. Der. Pharma Chemica, 2012; 4: 2442-2448.

62. Malassa H, Qutob Al M, Khatib Al Mahmoud, Rimawi Al F. Determination of different trace heavy metals in ground water of South West Bank/Palestine by ICP/MS. J of Environ. Prot.2013; 4: 818-827.

63. Hussain Z, Siddique S. Determination of Pesticides in Fruits and Vegetables 
using Acetonitrile Extraction and GC/MS technique. J of Sci. Res. 2010; 2: 19-29.

64. Sabale SR, Tamhankar BV, Dongare MM, Mohite BS. Extraction, Determination and Bioremediation of Heavy Metal Ions and Pesticide Residues from Lake Water. J Bioremed Biodegrad. 2012; 3:143.

65. Giordano, A.; Fernández-Franzón, M.; Ruiz, M.J.; Font, G.; Picó, Y. Pesticide Residue Determination in Surface Waters by Stir Bar Sorptive Extraction and Liquid chromatography/tandem Mass Spectrometry. Anal. Bioanal. Chem. 2009; 393:1733-1743.

66. Caldas, S.S.; Costa, F.P.; Primel, E.G. Validation of Method for Determination of Different Classes of Pesticides in Aqueous Samples by Dispersive liquid-liquid Microextraction with Liquid chromatography-tandem Mass Spectrometric Detection. Anal. Chim. Acta 2010; 665: 55-62.

67. Chandrakant S. Karigar and Shwetha S. Rao Role of Microbial Enzymes in the Bioremediation of Pollutants: A Review. Enzyme Research, Volume 2011, Article ID 805187, 1-11.

68. Vidali M, "Bioremediation. An overview," Pure and Appl. Chem. 2001; 73:1163-1172.

69.Leung M, "Bioremediation: techniques for cleaning up a mess," $\mathrm{J}$ of Biotech., 2004; 2:18-22.

70. Carrillo-Pérez E, Ruiz-Manriquez, A. Yeomans-Reina, H. Isolation, Identification and Evaluation of a mixed culture of microorganisms with capability to degrade DDT. Rev Int Contam Ambient. 2004; 20(2):69-75.

71. Lee SE, Kim JS, Kennedy IR, Park JW, Kwon GS, Koh SC, et al.
Biotransformation of an organochlorine insecticide, endosulfan, by Anabaena species. Journal of agricultural and food chemistry. 2003; 51(5):1336-40. Epub 2003/02/20.

72. Hussain S, Arshad M, Saleem M, Khalid A. Biodegradation of alpha- and betaendosulfan by soil bacteria. Biodegradation. 2007; 18(6):731-40. Epub 2007/01/26.

73. Kumar M. and Philip L., Bioremediation of endosulfan contaminated soil and water-optimization of operating conditions in laboratory scale reactors, J. Hazard Mater.,2006; 136: $354-364$.

74. Matsumoto E, Kawanaka Y, Yun SJ, Oyaizu H. Bioremediation of the organochlorine pesticides, dieldrin and endrin, and their occurrence in the environment. Applied microbiology and biotechnology. 2009; 84(2):205-16. Epub 2009/07/07.

75. Murthy HM, Manonmani HK. Aerobic degradation of technical hexachlorocyclohexane by a defined microbial consortium. Journal of hazardous materials. 2007; 149(1):18-25. Epub 2007/05/16.

76.Ortiz-Hernández M. L. and SánchezSalinas E., Biodegradation of the organophosphate pesticide tetrachlorvinphos by bacteria isolated from agricultural soils in México, Rev. Int. Contam. Ambient, 2010; 26(1), 27-38.

77. Boricha H. and Fulekar M. H., Pseudomonas plecoglossicida as a novel organism for the bioremediation of cypermethrin, Bio. Med., 2009; 1(4): 1-10.

78. Fulekar M.H., Bioremediation of fenvalerate by Pseudomonas aeruginosa in a scale up bioreactor, 
Roman Biotechnol. Lett., 2009; 14(6): 4900-4905.

79. Mohamed A.T., El Hussein A.A., El Siddig M.A. and Osman A.G., Degradation of oxyfluorfen herbicide by soil microorganisms: Biodegradation of herbicides, Biotechnol., 2011; 10:274-279.

80. Benimeli C.S., Fuentes M.S., Abate C.M. and Amoroso M.J., Bioremediation of lindanecontaminated soil by Streptomyces sp. M7 and its effects on Zea mays growth, Int. Biodeterior. Biodegrad., 2008; 61:233-239.

81. Pesce S. and Wunderlin D., Biodegradation of lindane by a native bacterial consortium isolated from contaminated river sediment, Int. Biodeter. Biodegr., 2004; 54:255-260.

82. Hernandez, M., Morgante, V., Avila, M., Villalobos, P., Miralles, P., Gonzalez, M.. and Seeger, M. Novel s-triazine-degrading bacteria isolated from agricultural soils of central Chile for herbicide bioremediation. Electron. J. Biotechnol. (In press) 2008.

83. Fujii, K., Takagi, K., Hiradate, S., Iwasaki, A. and Harada, N. Biodegradation of methylthio- striazines by Rhodococcus sp. strain FJ1117YT, and production of the corresponding methylsulfinyl, methylsul-fonyl and hydroxyl analogues. Pest Manag Sci 2007; 63: $254-260$

84. Vibber, L. L., Pressler, M. J. and Colores, G. M. Isolation and characterization of novel atrazinedegrading microorganisms from an agricultural soil. Appl. Microbiol. Biotechnol. 2007; 75: 921 - 928.

85. Martínez B., Tomkins J., Wackett L. P., Wing R. and Sadowsky M. J.,
Complete nucleotide sequence and organization of the atrazine catabolic plasmid pADP-1 from Pseudomonas sp. strain ADP, J. Bacteriol., 2001; 183: 5684-5697.

86. Shelton, D. R., Khader S., Karns, J. S. and Pogel, B. M. Metabolism of twelve herbicides by Streptomyces. Biodegradation. 1996; 7, 129-13.

87. Pardo, R., Herguedas, M. and Barrado, E. Biosorption of cadmium, copper, lead and zinc by inactive biomass of Pseudomonas putida. Analytical and Bioanalytical chemistry, 2003; 376 : 26-32.

88.Hussein H, Ibrahim SF, Kandeel K, Moawa $\mathrm{H}$. Biosorption of heavy metals from waste water using Pseudomonas sp. Electronic J. Biotechnol., 2004; 7(1).

89. Alam, M.Z, Ahmad, S. Chromium removal through biosorption and bioaccumulation by bacteria from tannery effluents contaminated soil. Clean-Soil Air Water, 2011; 39 : 226-237

90. Srinath, T., Verma, T., Ramteka, P. W. and Garg, S. K. Chromium (VI) biosorption and bioaccumulation by chromate resistant bacteria. Chemosphere, 2002; 48 : 427-435.

91. Tripathi, M., Jain, R. K., Vikram, S and Garg, S. K. Isolation and Growth Characteristics of Chromium (VI) and Pentachlorophenol Tolerant Bacterial Isolate from Treated Tannery Effluent for its Possible Use in Simultaneous Bioremediation. Indian J. Microbiol., 2011; 51 (1) : 61-69.

92. Andreonian, V., Colombo, M., Di Simine, D., Finoli, C., Origgi, G., Vecchio, A. and Carzaniga, R. Removal of lead from aqueous solutions by a Brevibacterium strain. In: Rosen, D. (Ed.) Modern 
agriculture and the environment. Kluwer Academic Publishers, Netherlands, 1997; 521-531.

93. Zaied KA, Abd El- Mageed HN, Fayzalla EA, Sharief AE, Zehry AA. Enhancement Biosorption of Heavy Metals from Factory Effluents via Recombinants Induced in Yeast and Bacteria. Austr. J. Basic Appl. Sci., 2008; 2(3): 701-717.

94. Salerno M. Research Report, Harmful effects of pesticides on Human health and safety Institute, www.cata-farmworkers.org 2014.

95. Hernández, AF., Parrón, T. and Alarcón, R. Curr Opin Allergy Clin Immunol. 2011; 11(2):90-6

96. Osburn, S.Research Report: Do Pesticides Cause Lymphoma? Lymphoma Foundation of America. Anne Arbor, MI 2001.

97. Roberts EM. Maternal Residence Near Agricultural Pesticide Applications and Autism Spectrum Disorders among Children in the California Central Valley. Environ. Health Perspect. 2007; 115(10).

98. Montgomery. Incident Diabetes and Pesticide Exposure among Licensed Pesticide Applicators: Agricultural Health Study, 1993-2003. American Journal of Epidemiology. 2008; 167(10):1235-1246.

99. Brown, T.P. Pesticides and Parkinson's disease - Is there a link? Environmental Health Perspectives 2006; 114(2):156-164.

100. Singh, R., Singh, P., Sharma, R. Microorganism as a tool of bioremediation technology for cleaning environment: A review. Proc. Int. Acad. Ecol. Environ. Sci., 2014; 4(1): 16.

101. United Nations Environment Programme, "The Aral Sea: Diagnostic Study for the
Development of an Action Plan for the Conservation of the Aral Sea," Nairobi, 1993.

102. World Health Organization, "Guidelines for Drinking Water Quality, Volume 1: Recommendations," 2nd Edition, Geneva, 1993.

103. Y. J. Wang and J. K. Lin, "Estimation of Selected Phenols in Drinking Water with in Situ Acetylation and Study on the DNA Damaging Properties of Polychlorinated Phenols," Archives of Environmental Contamination and Toxicology, 1995; 28:537-542.

104. S. R. Baker, "The Effects of Pesticides on Human Health," In: C. F. Wilkinson Ed., Advances in Modern Environmental Toxicology, 1990.

105. M. Margni, D. Rossier, P. Crettaz and O. Jolliet, "Life Cycle Impact Assessment of Pesticides on Human Health and Ecosystems," Agriculture, Ecosystems and Environment, Vol. 93, No. 1-3, December 2002, pp. 379-392.

106. G. R. Hallberg, "Pesticide Pollution of Groundwater in the Humid United States," Agriculture, Ecosystem and Environment, Vol. 26, No. 3-4, October 1989, pp. 299- 367.

107. McConnell. "Health Hazard Evaluation Report in Pesticides in the Diets of Infants and Children," Pesticides in the Diets of Infants and Children, National Academy Press, Washington, D.C., 1993.

108. Sawyer, C.N., McCarty, P.L. \& Parkin, G.F. Chemistry for environmental and Engineering and Science (fifth Edition), Mc Graw Hill, 2003; ISBN 0-07-248066-1, NY.

109. Col M, Col C, Soran A, Sayli BS, Ozturk S. Arsenic-related Bowen's disease, palmar keratosis, and skin 
cancer. Environ Health Perspect 1999;107:687-9.

110.Apostoli P. The role of element speciation in environmental and occupational medicine. Fresenius J Anal Chem 1999; 363: 499- 504.

111.Yamato N. Concentration and chemical species of As in human urine and hair. Bull Environ Contamin Toxicol 1988; 40: 633-40.

112. Lee MY, Jung BI, Chung SM. Arsenicinduced dysfunction in relaxation of blood vessels. Environ Health Perspect 2003; 111: 513-7.

113. Yoshida T, Yamauchi H, Fan Sun G. Chronic health effects in people exposed to arsenic via the drinking water: dose-response relationships in review. Toxicol Appl Pharmacol 2004; 198: 243- 52.

114. Sarkar M, Chaudhuri GR, Chattopadhyay A, Biswas NM. Effect of sodium arsenite on spermatogenesis, plasma gonadotrophins and testosterone in rats. Asian J Androl 2003; 5: 27-31.

115. Walton FS, Harmon AW, Paul DS, Drobná Z, Patel YM, Styblo M. Inhibition of insulin-dependent glucose uptake by trivalent arsenicals: possible mechanism of arsenic-induced diabetes. Toxicol Appl Pharmacol 2004; 198: 424-33

116. Agency for Toxic Substance and Disease Registry (ATSDR). Toxicological Profile for Arsenic U.S. Department of Health and Humans Services, Public Health Humans Services, Centers for Diseases Control. Atlanta 2003 a.

117. Chakraborti, D., Sengupta, M.K., Rahaman, M.M., Ahamed, S., Chowdhury, U.K. \& Hossain M.A. Groundwater arsenic contamination and its health effects in the GangaMegna-Brahmaputra Plain. $J$ of
Environ. Monit., 2004; 6: 74-83

118. Sakurai, T., Kojima, C., Ochiai, M., Ohta, T. \& Fujiwara, K. Evaluation of in vivo acute immunotoxicity of a major organic arsenic compound arsenobetaine in seafood. Int. Immunopharm. 2004; 4:179-184.

119.Mudhoo, A., Sharma, S.K., Garg, V.K. \& Tseng, C-H. Arsenic: an overview of applications, health, and environmental concerns and removal processes. Critical Reviews in Environmental Science \& Technology, 2011; 41: 435-519.

120. Schwarzenegger, A., Tamminen, T., \& Denton, J.E. Public health goals for chemicals in drinking water arsenic. Office of Environmental Health Hazard Assessment, California Environmental Protection Agency 2004.

121. Bhattacharya, P., Welch, A.H., Stollenwerk, K. G., McLaughlin, M.J., Bundschuh, J. \& Panaullah, G. Arsenic in the environment: Biology and Chemistry, Science of the Total Environment, 2007; 379:109-120.

122. Duxbury, J.M, Mayer, A.B., Lauren, J.G. \& Hassan, N. Food chain aspects of arsenic contamination in Bangladesh: effects on quality and productivity of rice. Journal of Environmental Science Health Part A, Environmental Science Engineering \& Toxic Hazard Substance Control, 2003; 38:61-69.

123. FAO/WHO Expert Committee on Food Additives, Arsenic. Available from http://www.inchem.org/documents/je cfa/jeceval/jec 159.htm 2005.

124. Joint FAO/WHO Expert Committee on Food Additives (JECFA). Safety evaluation of certain food additives and contaminants. WHO Food Additives Series No 52, 2004.

125. Uneyama, C., Toda, M., Yamamoto, 
M. \& Morikawa, K.. Arsenic in various foods: Cumulative data. Food Additives \& Contaminants, 2007; 24: 447-534.

126. Staessen JA, Roels HA, Emelianov D, Kuznetsova T, Thijs L, Vangronsveld J, et al. Environmental exposure to cadmium, forearm bone density, and risk of fractures: Prospective population study. Public Health and Environmental Exposure to Cadmium (PheeCad) Study Group. Lancet 1999; 353:1140-4.

127. Castro-González, M.I. \& MéndezArmenta, M. Heavy metals: Implications associated to fish consumption. Environmental Toxicology \& Pharmacology, 2008; 26:263-271.

128. Wu X, Jin T, Wang Z, Ye T, Kong Q, Nordberg G. Urinary calcium as a biomarker of renal dysfunction in a general population exposed to cadmium. J Occup Environ Med. 2001; 43: 898-904.

129. Henson MC, Chedrese PJ. Endocrine disruption by cadmium, a common environmental toxicant with paradoxical effects on reproduction. Exp Biol Med. 2004; 229: 383-92.

130. Benoff S, Jacob A, Hurley IR Male infertility and environmental exposure to lead and cadmium. Hum Reprod Update. 2000; 6:107-21.

131. Ye J, Wang S, Barger M, Castranova $\mathrm{V}$, Shi X. Activation of androgen response element by cadmium: a potential mechanism for a carcinogenic effect of cadmium in the prostate. $\mathrm{J}$ Environ Pathol Toxicol Oncol 2000; 19:275-80.

132. Apostoli, P. \& Catalani, S. Metal ions affecting reproduction and development. Metal Ions in Life Science, 2011; 8:263-303.

133. Agency for Toxic Substance and
Disease Registry (ATSDR). Draft Toxicological

Profile for Cadmium U.S. Department of Health and Humans Services, Public Health Humans Services, Centers for Diseases Control. Atlanta 2008.

134. WHO. Guidelines for drinking-water quality. Sixty-first meeting, Rome, 10-19 June 2003. Joint FAO/WHO Expert Committee on Food Additives, Avaible from http://ftp.fao.org/es/esn/jecfa/jecfa61 sc.pdf 2004 a.

135. Oehlenschläger, J. Identifying heavy metals in fish In: Safety and Quality issues in fish processing, Bremner, H.A. (Ed), pp. 95-113, Woodhead Publishing Limited, 2002; 978-184569-019-9, Cambridge.

136. Kaste JM, Friedland AJ, Sturup S. Using stable and radioactive isotopes to trace atmospherically deposited $\mathrm{Pb}$ in montane forest soils. Environ Sci Technol 2003; 37: 3560-7.

137. Tandon SK, Chatterjee M, Bhargava A, Shukla V, Bihari V. Lead poisoning in Indian silver refiners. Sci Total Environ 2001; 281: 177-82.

138. Siddiqui MK, Srivastava S, Mehrotra PK. Environmental exposure to lead as a risk for prostate cancer. Biomed Environ Sci 2002; 15: 298-305.

139. Lindbohm ML, Sallmen M, Anttila A, Taskinen H, Hemminki K. Paternal occupational lead exposure and spontaneous abortion. Scand J Work Environ Health 1991; 17: 95-103.

140. Ming-Ho, Y. Environmental Toxicology: Biological and Health Effects of Pollutants, Chap. 12, CRC Press LLC, ISBN 2005; 1-56670670-2, 2nd Edition, BocaRaton, USA

141. Agency for Toxic Substance and Disease Registry (ATSDR). Toxicological Profile for Lead U.S. 
Department of Health and Humans Services, Public Health Humans Services, Centers for Diseases Control. Atlanta 2007.

142. Tokuomi H, Kinoshita Y, Teramoto J, Imanishi K. Hunter-Russel Syndrome. Nippon Rinsho 1977; 35(1): 518-9.

143. Mudgal V, Madaan N, Mudgal A, Singh R.B, Mishra S. Effect of toxic metals on human health. The open nutra. J.2010; 3: 94-99.

144. Bittner AC Jr, Echeverria D, Woods JS, Aposhian HV, Naleway C, Martin $\mathrm{MD}$, et al. Behavioral effects of lowlevel exposure to Hgo among dental professionals: A crossstudy evaluation of psychomotor effects. Neurotoxicol Teratol 1998;20:42939.

145. Grandjean P, Guldager B, Larsen IB, Jorgensen PJ, Homstrup P. Placebo response in environmental disease. Chelation therapy of patients with symptoms attributed to amalgam fillings. $J$ Occup Environ Med 1997;39:707-14.

146. Nierenberg DW, Nordgren RE, Change MB, Siegler RW, Blayney MB, Hochberg F, et al. Delayed cerebellar disease and death after accidental exposure to dimethylmercury. New Engl J Med 1998;338:1672-6.

147. Mahurpawar M. Effects of heavy metals on human health. Int. $\mathrm{J}$ of Res. - Granthaalayah, 2015; ISSN2350-0530(O) ISSN- 2394-3629(P), 1-7.

148. CPCB, 2006-2007. Water Quality Status of Yamuna River, Assessment and Development of River Basin Series: ADSORBS/41/2006-2007. Published by Central Pollution Control Board (CPCB), Delhi, India.

\section{How to cite this article:}

Nupur Raghav and Shrivastava, J.N. 2016. Toxic Pollution in River Water and Bacterial Remediation: An Overview. Int.J.Curr.Microbiol.App.Sci.5(4): 244-266. doi: http://dx.doi.org/10.20546/ijcmas.2016.504.030 